Revue bibliographique pour le domaine irano-aryen

Volume 23 | 2002

Comptes rendus des publications de 2000

\title{
A Survey of Neo-Elamite History. State Archives of Assyria Studies XII, Helsinki, Institute for Asian and African Studies, 2000, (The Neo-assyrian Text Corpus Project) xviii-139 p. index général, index des sources.
}

Rémy Boucharlat

\section{CpenEdition}

Édition électronique

URL : http://journals.openedition.org/abstractairanica/35240

DOI : 10.4000/abstractairanica.35240

ISSN : 1961-960X

Éditeur :

CNRS (UMR 7528 Mondes iraniens et indiens), Éditions de l'IFRI

Édition imprimée

Date de publication : 15 mai 2002

ISSN : 0240-8910

\section{Référence électronique}

Rémy Boucharlat, « A Survey of Neo-Elamite History. State Archives of Assyria Studies XII, Helsinki, Institute for Asian and African Studies, 2000, (The Neo-assyrian Text Corpus Project) xviii-139 p. index général, index des sources. », Abstracta Iranica [En ligne], Volume 23 | 2002, document 57, mis en ligne le 08 février 2010, consulté le 25 septembre 2020. URL : http://journals.openedition.org/ abstractairanica/35240 ; DOI : https://doi.org/10.4000/abstractairanica.35240

Ce document a été généré automatiquement le 25 septembre 2020.

Tous droits réservés 


\title{
A Survey of Neo-Elamite History. State Archives of Assyria Studies XII, Helsinki, Institute for Asian and African Studies, 2000, (The Neo- assyrian Text Corpus Project) xviii-139 p. index général, index des sources.
}

\author{
Rémy Boucharlat
}

1 A côté des histoires de l'Élam, dont seule celle de M. Stolper en 1984 reste encore actuelle, il manquait une étude plus spécifique pour les derniers siècles de cet état (1000-550 av.n.è.), entre la période des grands bâtisseurs de choga Zanbil et des conquérants de la Babylonie, et la prise de pouvoir par les Perses. C'est une histoire politique, surtout dynastique et militaire, que propose l'A. qui a rassemblé les sources écrites disponibles, la Chronique babylonienne, les textes assyriens, surtout pour le $7^{\mathrm{e}}$ s., et des sources plus disparates mais largement élamites pour le dernier siècle. Le tableau reste flou sur l'organisation politique, l'existence de un ou plusieurs royaumes, leurs limites géographiques: le défaut est dû aux sources et non à l'auteur. Cette situation est frustrante, si on se souvient que le $7^{\mathrm{e}}$ et le début du $6^{\mathrm{e}} \mathrm{s}$. correspondent à l'émergence dans le Fars du royaume perse, dont héritera Cyrus. La genèse de l'empire reste donc très mal connue. Pour l'état de la documentation écrite sur le S.O. de l'Iran et son analyse, le livre de M.W. sera une référence. 
INDEX

Thèmes : 3.2.2. Pré-Achéménides et Achéménides

\section{AUTEURS}

RÉMY BOUCHARLAT

CNRS - Lyon 